Journal of Business \& Management (COES\&RJ-JBM)

ISSN (E): 2306-7179 ISSN (P): 2306-8043

Publisher: Centre of Excellence for Scientific \& Research Journalism, COES\&RJ LLC

Online Publication Date \& Issue: 1st October 2017, Vol.5, No.4, October 2017

https://doi.org/10.25255/jbm.2017.5.4.167.187

\title{
MEASURING JOB SATISFACTION, PERFORMANCE CRITERIA AND JOB LIFE QUALITY: BINGOL CITY BANKING CASE
}

\author{
Imran Aslan, \\ Assist.Prof. \\ Bingöl University, Healthcare Faculty, \\ Numerical Science, 1200, Bingöl-Turkey
}

\begin{abstract}
:
Job satisfaction, performance and quality of life have strong effects on each other. Happy workers are to perform higher productivity and have less stress in their daily life.Two different studies in 2016 were applied to banks in Bingol city/Turkey to learn the level of job satisfaction,performancecriteria and life quality of workers. 42 surveys were applied to determine job satisfaction and expectations and evaluation ofperformance criteria factors. Second survey were applied 19 workers to learn the life quality of workers. Descriptive statistics (means and frequency methods), t-test and Kruskal Wallis methods are applied to analyze data. The average age of staffs is in young period with 2500-3500 TL(も) average salary and they have 3-8 years bank experience mainly. High salary and job security are the main expectations of workers. Talking freely and discussing issues with 9.19 mean is found to be the most important item with managers according priority of workers as a part of job satisfaction. The physical working conditions and other opportunitiesoffered by the bank and wages are the worst items with lowest scores. Younger workers thinks that they get more feedback about their work while older people getting not enough feedbacks. About $15.8 \%$ of them see themselves in a kind of depression and just $36.8 \%$ of them are happy according to second survey.Complying with working hours, well-suited appearance and relationships with managers are most effective factors for performance.
\end{abstract}

\section{Keywords:}

Job Satisfaction, Life Quality, Banking Performance Criteria, Bingöl

\section{Citation:}

Aslan, Imran (2017), Measuring job satisfaction, performance criteria and job life quality : Bingol City banking case; Journal of Business \& Management (COES\&RJ-JBM)

Vol.5,No.4,pp.167-187, https://doi.org/10.25255/jbm.2017.5.4.167.187.

This work is licensed under a Creative Commons Attribution 4.0 International License. 


\section{Introduction}

"You can't have happy customers served by unhappy employees" is stated by Heskett et al., (1997) that Job Satisfaction and performance have strong correlation with each other since "Happy employees are more productive than productive employees are happier" is stated by Wilkinson\& Wagner (1993). Workers have more motivation when the physical and physic-social factors are supportive at doing their job. Moreover, costumers are to be more satisfied if their requirements are met by motivated workers. Banking sector is more service intense field and workers are to interact with costumers continuously. Nature of work, working hours, coordination with fellow workers, promotion and advancement, overtime, physical environment, types of management, participation, rewards, understanding emotions, personal circulation, social activities, problem solving abilities, organization culture and physical health of workers are main variables of job satisfaction. Positive emotional state is created by the degree of fulfilling needs of individuals. Actual outcomes of workers are to be desired, anticipated or deserved that workers can measure their expectations. Hence, transparency at performance evaluation can increase the trust to the performance evaluation and management authority. Moreover, life quality of workers can increase if they have less problems at work and fully motivated.

Minnesota satisfaction questionnaire is widely used to measure job satisfaction based on activities, independence, variety, social status, supervision, moral, job security, authority, abilities, policies, advancement, creativity, work conditions, recognition, achievement, co-workers etc. Most theory of job satisfaction is driven from these factors and many studies have been done by using that scale. This study also aims to measure the factors affecting performance, satisfaction level at current position and expectations/importance, determining applied performance method, responsible authorities of performance evaluation, expectations from work, enjoyment of current work, image of current job, appropriation of management and co-workers, cooperation with work friends, problem solving skills of organization, the supports of management at solving social and economical problems, salary adequacy, physical and economical conditions provided by organization and ethical considerations of job. This study is generally based on assumption that job satisfaction and performance have strong positive correlation.

There are nine branches of different banks in Bingöl city. Vakif bank with vakif participation bank, halk bank and ziraat banks are mainly governmental banks. Deniz bank, İş bank, Türkiyefinans bank, Kuveyt 
Measuring job satisfaction, performance criteria and job life quality: Bingol City banking case

bank, PTT Bank and Garanti banks are private banks. Participation/Islamicbanks :Kuveyt, Ziraat, Turkiyefinans and Vakifare new banks and the oldest one is the Turkey Finans bank. Bingöl city is a growing city with its conservative life style as stated by Aslan (2017). The religious considerationsof staffs and costumers have been changing with new banking styles. This study aims to measure the current performance system and job satisfaction of 87 workers in all banks. The second study was carried out to measure the life quality workers. Both studies were carried out in 2016 year. Work-life balance has strong tie-up from literatureand many work problems can be carried home and create depressions or burnouts.

\section{Literature review}

Job satisfaction defined as "an attitude reflecting a person's feelings towardhis or her job or job setting at particular point in time" by Schermerhon et al. (2012) and"apositive attitude toward one's job" by Daft and Marcic (2013) are most widely used definitions of job satisfaction in literature. So Job Satisfaction is an effective reaction to one's job. It is a combination of expectations of individual and what gotten from a job according to Singh(2009). Retention, productivityand a higher level of service quality found through study of Abiyevet al. (2016) are created by satisfied employees. The creation of superior value, customer satisfaction, competitive advantage, growth, and profitability are done by service excellence through service orientation being different from its competitors, and surpass the competition with meeting the needs of customers, and delivering superior value to them. Customer treatment creating positive perceptions of service performance, employee empowerment, servant leadership setting service examples, service vision communicating a service vision for the organization, service training, service rewards, service failure prevention, service failure recovery dealing with existing service problems, service technology using technology to deliver good services and service standards communication expectations from all employees in terms of service standards, practices and behaviors are basic ingredients for creating and producing excellent services. It is found that service orientation have positive correlation with job satisfaction, customer satisfaction and financial performance.Moreover, increased job satisfaction increases customer satisfaction resulting better financial performance. (Eren et al., 2013 )Work slow-down, high absenteeism and turnover leading low performance are mainly due to low job satisfaction. High level of job stress, lack of communication, lack of recognition, limited opportunity for growth, poor leadership approaches, unfavorable 
management practices, etc. are found reasons of low motivation. Salary\& remuneration as first one, training \& development opportunities as second most important reason,nature of work, promotion opportunities, working condition, and performance appraisal are found main factors increasing job satisfaction in Nepal. There are not enough significant differences that job satisfaction increases financial performance of a bank in that country. (Gautam, 2016) Salary of employees, performance appraisal system, promotional strategies, employee's relationship with management and other co- employees, training and development program, work burden and working hour factor are found effective factors for job satisfaction at Canara Bank employees in Delhi, India. Design, air quality and temperature, noise and lighting, ability of employees to personalize their workspaces and workspace design and management etc. also affect work satisfaction. (Aartichahal et al., 2013) Job commitment promise of doing the job is crucial for organizational goals with work through self-sacrifice. It increases job satisfaction, higher organizational commitment, and lower intention to leave the job. (Nabi et al., 2017) The organizational commitment, job content and job involvement have direct effect on job satisfaction. The quality of work life, organizational climate, job involvement and organizational commitment have also positive effect on job satisfaction. The salary, the promotion policy of the company, the attitudes of the co-workers, the physical and mental stress levels involved, the working conditions, the interest and challenge level are related the job itself. Salary, efficiency in work, fringe supervision, and co-worker relation were found the most significant factor on job satisfaction from a study done in Bangladesh with higher satisfaction at private banks than public banks. (Islam, 2014)

External factors such as equipment, technology and finance play important role in working life and production capacity resulting in better job satisfaction and performance. Socio-demographic and cultural factors such as professional attitude towards job, tolerant outcomes and emotional values affect the job satisfaction of employees. Human resource conventions such as quality education, market oriented training, career planning, workers' empowerment and performance evaluation are other important parameters of organizational development. Furthermore, freedom of performance, team work, engagement and compensation can help employees to be more motivated and increase their capabilities. Inadequate salary structure, lack of opportunities, weak incentive schemes for excellent job performance, promotion code based on seniority rather than actual performance, delays in promotion, non-existent compensation modules, punitive treatment and absence of motivational strategies are 
factors affecting low performance according to Zheng \&Lamond (2010). Training, empowerment and reward were found three important criteria of human resource from study of Sattar et al.( 2015) for improving quality of performance. Providing good working conditions can increase the job satisfaction in order to achieve the organizational goals and objectives with flexible working hours, less work load, a team work approach and a supportive top management. Wages, working hours, autonomy given to employees, organizational structure and communication between employees \& management are important factors effecting job satisfaction. Not giving employees enough respect and harsh behaviors to themcreate dissatisfaction. (Raziq\&Maulabakhsh, 2015 ) Employment, learning and evolution, labor relations and working conditions, health, safety, prosperity, fulfillment of regulatory requirements, equal opportunities etc. relating to the employment relationship are parts of organizational culture allowing employees to use their potential maximally for organization targets and differing in public and private organizations. Individual characteristics, attitudes and preferences affecting the organizational culture are to be known by management of organization. Women prefer a more friendly-family working environment while men prefer more competitive environment. (Belias\&Koustelios, 2014) Working hours, lack of proper training and development efforts of the employees and the frequent transfers of the employees were found dissatisfaction reasons in that study. (Cahal et al.,2013) Creating a win-win solution in banks can also increase job satisfaction. A transparent standing policy for promotion of employees was found to create a competitive atmosphere and allows to being fair for staffs. Furthermore, insurance coverage, leave and other fringe benefits can increase job satisfaction by increasing job security. (Ahmed \& Uddin,2012) It is found by Leontaridi \& Sloane (2001) that low-pay workers have more satisfaction than other workers. A threshold for wage was found to increase job satisfaction but after that a threshold wage does not have an effect on job satisfaction.

Low occupational stress, high job performance, low turnover intention and low psychological distress results are found with higher job satisfaction. Role conflict the incompatibility of requirements and expectations from the role and ambiguity create lower satisfaction. Autonomy gaining greater control over the planning and implementation of their tasks and increasing the employees' control and decision making increase job satisfaction and decrease work stress. Heavy workload can cause occupational stress and burnout. (Belias et al., 2015)Occupational stress has negative impact on life satisfaction and work-life balance as well as on job performance and job 
satisfaction. Role demands (role overload, role ambiguity, role conflict), poor working conditions, poor interpersonal relationships, group and political pressures, lack of participation, job insecurity, lack of career advancement, unsound financial benefits etc. can create stress at work. Stress up to certain level is necessary but too much may create illnesses. Recreational activities (e.g. music, sports), management and utilization of free times and weekends, regular exercise, and moderate food and drinks (avoiding excessive consumption of coffee, tea or cigars) may decrease stress. (Ukil\&Ullah, 2016) A good workplace with competitive wages, trusting relationship between the employees and management, equity and fairness for everyone, and a sensible work load with challenging yet achievable goals and physical work environment can increase job satisfaction with less stress, no bullying, working requirements, cooperation and less conflicts, etc. Moreover, social work environment with good communication styles, relationship between superiors and subordinates improve the job satisfaction. (Agbozo et al., 2017)

Transformational leadership motivating their subordinates to perform at a higher level by inspiring them, offering them intellectual challenges and paying attention to their individual needs and transactional leadership focusing on specific goals and agreed-upon rewards are effective leadership models widely applied in banking sector. (Belias, \&Koustelios, 2014)Interactive leadership style and communication competency were found to have strong effect on job satisfaction of bank employees in Turkey from a 225 respondents survey. Listening and negotiating skills of the managers are crucial factor for communication competency and transformational leaders focusing on increasingintrinsic motivation and personal development are found to be more effective at increasing job satisfaction of employees. Negative leader-employee interactions can cause to high stress, reduced productivity, increased absenteeism and turnover with unwilling employees to work and aggression, complaining, fighting, psychological withdrawal and quitting the job behaviors. Decreased employee performance, tardiness, absenteeism and early retirements are main results of these interactions. (Çetin et al., 2012) It is found from study of Mishra et al.(2016) that there is a positive correlation between optimism(positive thinking and expectations) and job satisfaction and financial performance. Pessimistic people are very doubtful and hesitate at doing works. Minimal importance is given past events by optimistic people learned mainly by training. Employee participation in the decision making and managementmakes employees happy in context oftheir mind, increasing performance and job satisfaction. Positive communication has an effect on productivity, employee motivation, 
employee commitment, job satisfaction, job security and transparency, improvement of workplace, recognition of performance, feeling of belonging, relationship with superiors and peers and stimulation to attain company's goals. A feeling of belonging to the organization has also increased job satisfaction. (Nabiet al., 2017) Bullying continuously and making negative comments to decrease the motivation of staffs increase the burnout at work place. It is found that too much pressure from top hierarchy to down and grouping by isolating other workers decrease the productivity. Many workers are afraid of losing the job and thus they stay silence this kind of mobbing. (Aslan \& Bektaş, 2016) Jobinsecurity regards as not preservation employment status and a perceived threat regarding the job with the sense of powerlessness to do anything about that very threat is negatively correlated with job satisfaction and cause health problems in long term with a decrease in both physical and mental health status, reduced job performance, and lower job involvement. (Yaşlığlı et al., 2013)

Ryan and Deci (2000) state that "Intrinsic motivation refers to doing something because it is inherently interesting or enjoyable and it is found by Çınaret al., (2011) that intrinsic factors are more motivating than extrinsic factors. Azash et al. (2011) stated motivation and hygiene factors differing in public sector with achievement, advancement, interpersonal relations, working conditions, policy and personal life and private sector with perceive achievement, interpersonal relations, supervision, and policy as motivational factors bank employees. Bank employees from public and private banks in North Cyprus showed that employees are satisfied with the intrinsic and extrinsic aspects of their job. Training and development programs, enriching their job, career paths, more autonomy, less of a formal hierarchical relationship, more open channels of communication management and the employee rewarding system are factors increasing job satisfaction. (Saner\&Eyupoglu, 2014) The job life is not just a source of income but also an important part of life and social standing. From 149 employees of Islamic banking in Bandar Lampung in Indonesia, Islamic work ethics being consistent with the rulesand stipulations of the religion have greater effect on intrinsic motivation and organizational commitment than job satisfaction and job performance. (Hayati\&Caniago, 2012) Doing halal things increases the motivation of Muslim staffs with obeying the rules of Islam by Aslan \& Aslan(2016) as an intrinsic factor. Hence, especially staffs at participation bank can be more willing if they do their jobs according to Islamic rules. Furthermore, intrinsic factors such as opportunities for advancement and growth, recognition, responsibility, 
achievement) promote job satisfaction and extrinsic factors such as supervision, pay, policies, working conditions, interpersonal relations, security are main category for job satisfaction. Expectancy model is also used to explain the motivation of staffs at organizations. (Chahal et al., 2013)

\section{Research methodology}

First study was applied to all banks in Bingöl city in 2016. Survey questions were taken from studies of Bayir et al.(2016) and Bakan\&Kelleroğlu (2003) studies. The second questionnaire was conducted by interviewing the participating banks and other bank employees (TürkiyeFinans, VakıfbankveZiraatt Banks) in Bingöl city, Turkey in 2016. A total of 19 participants participated in the survey, of which are $52.6 \%$ male and $9.4 \%$ female by asking common questions measuring life quality. To analyze the data, frequency, descriptive statistics and analyses of variance methods are used by SPSS 20 computer program.

\section{Results and discussion \\ First Survey Results}

$59.5 \%$ of respondents are male and $57.1 \%$ of them have children as shown in Table $1.50 \%$ of them are in 30-40 age range that the majority of them are at middle age and $42.9 \%$ of them are in 20-30 age range. It can be said that the workers of banksare mainly young staffs. 54.8\% of them have 3-8 years experience at bank and about $30 \%$ of them have less than 3 years experience. $54.8 \%$ of them have graduate degrees and just $23 \%$ of them have master degrees. Furthermore, $69 \%$ of them mainly work at counters and they are mainly assistant. $57.1 \%$ of them work at government banks and $38.1 \%$ of them work at private banks. 
Measuring job satisfaction, performance criteria and job life quality: Bingol City banking case

Table 1: Demographic variables

\begin{tabular}{|c|c|c|c|c|c|}
\hline Parameter & Freq. & Percent(\%) & Parameter & Freq. & Percent $(\%)$ \\
\hline \multicolumn{3}{|l|}{ Gender } & \multicolumn{3}{|c|}{ Having Children } \\
\hline Female & 17 & 40.5 & Yes & 18 & 42.9 \\
\hline Male & 25 & 59.5 & No & 24 & 57.1 \\
\hline Total & 42 & 100.0 & Total & 42 & 100.0 \\
\hline \multicolumn{3}{|l|}{ Age } & \multicolumn{3}{|c|}{ Experience years at Bank } \\
\hline $20-30$ & 18 & 42.9 & $<1$ year & 7 & 16.7 \\
\hline $30-40$ & 21 & 50.0 & 1-3 year & 6 & 14.3 \\
\hline $40-50$ & 3 & 7.1 & 3-8 year & 23 & 54.8 \\
\hline Total & 42 & 100.0 & $8-15$ year & 4 & 9.5 \\
\hline \multicolumn{3}{|l|}{ Education Level } & $15+$ & 2 & 4.8 \\
\hline High School & 3 & 7.1 & Total & 42 & 100.0 \\
\hline Pre-license & 6 & 14.3 & \multicolumn{3}{|c|}{ Working Unit } \\
\hline Graduate & 23 & 54.8 & Counter & 29 & 69.0 \\
\hline Master & 10 & 23.8 & $\begin{array}{l}\text { Costumer } \\
\text { Relationship }\end{array}$ & 13 & 31.0 \\
\hline Total & 42 & 100.0 & Total & 42 & 100.0 \\
\hline \multicolumn{3}{|l|}{ Position } & \multicolumn{3}{|c|}{ Working Bank } \\
\hline $\begin{array}{l}\text { Assistant- } \\
\text { authorized }\end{array}$ & 32 & 76.2 & Government & 24 & 57.1 \\
\hline Career group & 5 & 11.9 & Private & 16 & 38.1 \\
\hline Branch managers & 5 & 11.9 & \multirow[t]{2}{*}{ Total } & \multirow[t]{2}{*}{40} & \multirow[t]{2}{*}{95.2} \\
\hline Total & 42 & 100.0 & & & \\
\hline
\end{tabular}

With 2.8 mean (1-5 Likert-very happy to not happy), workers are not happy at position they work. Just $42.9 \%$ of them are happy with position they work while $19 \%$ of them are not at all satisfied. Workers average at working different banks is 1.37 that they mainly work in a bank until now. $57.1 \%$ of workers have 1501-2500 TL(も) salary and theaverage of salary is between 2500-3500 TL( $($ ) that the average salary is high for a city like Bingöl not having expensive economical life when compared big cities like Istanbul. The main evaluation for performance is done by manager of bank with $95.5 \%$. Costumers with $7.1 \%$ frequency are not effective factor on performance of workers. Moreover, management and work colleagues are not also effective at evaluation of performance. According to respondents, overall behaviors evaluation is themost effective factor on performance. Later predefined criteria and registry review manager make performance with $50 \%$ as shown in Table 2. Continuous following and taking notes is stated as the third method that there are not continuous controls on workers for performance evaluation. 
Table 2:Performance evaluation authority

\begin{tabular}{|l|c|c|}
\hline Performance evaluation method & Freq. & Percent(\%) \\
\hline Predefined criteria and registry review manger & 21 & 50.0 \\
\hline Overall behaviors evaluations by registry review manger & 23 & 54.8 \\
\hline Comparing with other colleagues at the same ranking & 15 & 35.7 \\
\hline Continuous following and taking notes & 17 & 40.5 \\
\hline $\begin{array}{l}\text { The aims and results to be achieved are determined together with } \\
\text { the subordinates and superiors }\end{array}$ & 15 & 35.7 \\
\hline Others & 5 & 11.9 \\
\hline
\end{tabular}

The highest expectation of staffs from works is high salary as shown in Table 3 with $83.3 \%$. Job security is found as the second highest expectation with $64.3 \%$ and other important expectation is having career opportunities. Foreign country opportunitieshave the lowest mean expectancy with $7.1 \%$. Having the reward system, possibility of team work, good technical ability, less bureaucracy, educational opportunity, creativity, flexible hours, the existence of social services, gaining a good environment and female staff-friendly approach items have low frequency that banks do not care much development side and merits of staffs. These properties like creativity and technical abilities are to help staffs to get promotions opportunities in institutionalized banks.

Table 3: Expectations from work

\begin{tabular}{|l|c|c|}
\hline Expectations from work & Freq. & Percent(\%) \\
\hline A good salary & 35 & 83.3 \\
\hline Safe environment & 15 & 35.7 \\
\hline Job security & 27 & 64.3 \\
\hline Good colleagues & 18 & 42.9 \\
\hline Educational opportunity & 8 & 19.0 \\
\hline Less bureaucracy & 7 & 16.7 \\
\hline Having the reward system & 5 & 11.9 \\
\hline Creativity & 8 & 19.0 \\
\hline The existence of social services & 10 & 23.8 \\
\hline Personal evolution & 16 & 38.1 \\
\hline Gaining status & 19 & 45.2 \\
\hline Good and reliable managers & 17 & 40.5 \\
\hline Gaining a good environment & 9 & 21.4 \\
\hline Have career opportunities & 26 & 61.9 \\
\hline Foreign country opportunities & 3 & 7.1 \\
\hline Good technical ability & 6 & 14.3 \\
\hline Flexible hours & 10 & 23.8 \\
\hline Giving authority and responsibility & 13 & 31.0 \\
\hline Female staff-friendly approach & 12 & 28.6 \\
\hline Possibility of team work & 7 & 16.7 \\
\hline
\end{tabular}


Measuring job satisfaction, performance criteria and job life quality: Bingol City banking case

\section{Measuring Job Satisfaction}

To learn job satisfaction, 1-10Likertscale is applied in three ways: how much currently1-10(very little to very much), how much it should be110(very little to very much) and the importance of that item1-10(Not important to very important). A three- score is chosen to each item to learn current status, expectation from that item and importance.

- In terms of satisfaction, "the degree of loving work" has currently 5.73 mean and 8.68 mean is the expected score from that item. With 8.83 mean, this item is very important for the workers. It can be said that they are not sure that they love their work and neutral on that item.

- "Seeing banking work as a respectable business and the degree of your success and pride in profession" itemhas currently mean of 6.9 and the expectation is high with 8.6 mean. The importance of that item for them is8.97 mean.

- "Appropriation and appreciate your managers" item's current, expected degree and importance are 6.8, 8.57 and 9 means that the management appropriation and appreciate level are good and it is very important for the staffs. Transformational leadership motivating style may be applied to the bank to increase job satisfaction of employees.

- "Appropriation and appreciate your colleagues" item's current, expected degree and importance are 7.4, 8.6 and 8.92 means that the employees have more satisfied results with their work friends. Increasing communication, organization wide activities can help employees to be integrated.

- "Your level of understanding/coordination with your managers and colleagues, and the level of your professional support" item's current, expected degree and importance are 7.41,8.65 and8.97 meansrespectively that work relationships with management and colleagues are high and it can be increased.

- "You can freely discuss and make suggestions by discussing issues related to your business or the way you do business with your managers" item's current, expected degree and importance are6.6, 8.78 and 9.19 means respectively that the current situation of solving work related problems is not at good level and it is expected to be increased that this item has very important priority at increasing job satisfaction.

- "Your level of support you see from your management and your managers in solving your personal, social or economic problems" item's current, expected degree and importance are 6.17, 8.57 and 8.92 means respectively that there is 2.4 mean difference from expected support and management is not enough successful at supporting workers personal, social or economic problems 
- "The rate of adjustment of your wage with your work" item's current, expected degree and importance are 4.9, 8.58 and 8.88 means respectively that the workers expect higher wages and the wage is very important for them. As stated in literature that monetary supports have high effect on satisfaction.

- "The physical working conditions and conditions offered by your bank" item's current, expected degree and importance are 5.62, 8.42 and 8.95 means respectively that the physical factors do not meet the expectations of staffs.

- "The level of alignment of your ethical values with the work you do" item's current, expected degree and importance are 6.87, 8.73 and 9.07 means respectively that ethical considerations is currently align with their ethical values. Participation bank staffs care more about the halal(catering according to Islam) of their transactions.

\section{Measuring Performance}

1-5(very considerable to not considered very much) Likert scale is used to find important factor affecting the performance according to workers. Sensitivity to comply with working hours has the highest mean on performance that banks care and controls working hours. Later always having a clean and well-maintained appearance item has the high mean that banking staffs are to be well dressed. Then good relationships with superiors and subordinates and keeping the institution's policies, strategies and general objectives in front of their own aims items have high effect on evaluation of performance. The strength of the social side, ability to use technological tools, a tendency to focus on team success rather than selfsuccess and difficulties in personal life are not reflected in business life items have the least effects respectively as shown in Table 4. 
Measuring job satisfaction, performance criteria and job life quality: Bingol City banking case

Table 4: Descriptive statistics of performance consideration

\begin{tabular}{|l|c|c|c|}
\hline $\begin{array}{l}\text { Item(According to you which factors are taken } \\
\text { into consideration } \\
\text { performance) }\end{array}$ & Freq. & Mean & $\begin{array}{l}\text { Standard } \\
\text { Error }\end{array}$ \\
\hline $\begin{array}{l}\text { Giving personal feedback on the performance of } \\
\text { the person }\end{array}$ & 42 & 1.9762 & 1.13671 \\
\hline $\begin{array}{l}\text { Sufficient technical information about the job of } \\
\text { the person }\end{array}$ & 42 & 2.0000 & 1.01212 \\
\hline $\begin{array}{l}\text { The ability of the person to make decisions on his } \\
\text { own }\end{array}$ & 42 & 2.1905 & 1.25403 \\
\hline Customer-oriented attitude towards the customer & 42 & 1.8810 & 1.01699 \\
\hline Using time well & 42 & 1.8810 & 1.04069 \\
\hline The strength of the social side & 41 & 2.5610 & 1.43263 \\
\hline Ability to use technological tools & 42 & 2.4048 & 1.23089 \\
\hline High persuasiveness & 42 & 1.7857 & 1.11608 \\
\hline $\begin{array}{l}\text { Always having a clean and well-maintained } \\
\text { appearance }\end{array}$ & 42 & 1.6190 & 1.03482 \\
\hline Good relationships with superiors and subordinates & 42 & 1.6667 & 0.90167 \\
\hline Prone to teamwork & 42 & 2.0238 & 1.11504 \\
\hline $\begin{array}{l}\text { A tendency to focus on team success rather than } \\
\text { self-success }\end{array}$ & 42 & 2.3571 & 1.24590 \\
\hline $\begin{array}{l}\text { Difficulties in personal life are not reflected in } \\
\text { business life }\end{array}$ & 41 & 2.3171 & 1.38634 \\
\hline Ability to learn new tasks and volunteerism & 42 & 2.2619 & 1.21092 \\
\hline Can do more quantitatively & 42 & 2.0238 & 1.17884 \\
\hline $\begin{array}{l}\text { Qualitatively good quality and able to do good } \\
\text { work }\end{array}$ & 42 & 2.0476 & 1.24846 \\
\hline Ability to develop new ideas & 42 & 2.1905 & 1.21451 \\
\hline Commitment to the Corporation & 42 & 1.9250 & 1.22762 \\
\hline Sensitivity to comply with working hours & 42 & 1.6905 & 0.94322 \\
\hline $\begin{array}{l}\text { Keep the institution's policies, strategies and } \\
\text { general objectives in front of their own aims }\end{array}$ & & 0.97501 \\
\hline
\end{tabular}

\section{Comparing Differences Statistically}

According to Kolmogorov-Smirnov and Shapiro-Wilk tests,sig values are smaller than 0.05 that data are not normally distrusted and sample size is smaller than 30.Thus, independent samples $t$ test is used to find statistical differences according to gender. Women shows less appropriation and appreciation to the colleagues and female respondents stated that they get along well with managers and colleagues with high cooperation as shown in Table 5. 
Table 5 : Gender differences

\begin{tabular}{|c|c|c|c|c|c|c|c|}
\hline Item & $\mathbf{F}$ & $\begin{array}{l}\text { Gende } \\
\mathbf{r}\end{array}$ & Freq. & Mean & $\mathbf{t}$ & df & $\begin{array}{l}\text { Sig. (2- } \\
\text { tailed) }\end{array}$ \\
\hline \multirow{2}{*}{$\begin{array}{l}\text { According to your job } \\
\text { satisfaction.Appropriationan } \\
\mathrm{d} \text { appreciation your } \\
\text { colleagues, Now how much }\end{array}$} & \multirow[t]{2}{*}{7.2} & Female & 17 & 7.23 & \multirow[t]{2}{*}{2.0} & \multirow[t]{2}{*}{34} & \multirow[t]{2}{*}{0.04} \\
\hline & & Male & 25 & 7.52 & & & \\
\hline \multirow{2}{*}{$\begin{array}{l}\text { According to your job } \\
\text { satisfaction. Your level of } \\
\text { getting along with your } \\
\text { managers and colleagues, } \\
\text { and the degree of your } \\
\text { professional cooperation, } \\
\text { How important this is to } \\
\text { you. }\end{array}$} & 0.1 & Female & 17 & 9.4 & \multirow[t]{2}{*}{1.9} & \multirow[t]{2}{*}{39} & \multirow[t]{2}{*}{0.05} \\
\hline & & Male & 25 & 8.64 & & & \\
\hline
\end{tabular}

According to Kolmogorov-Smirnov and Shapiro-Wilk tests, that data are not normally distributed hence Kruskalwalis test is used to test differences. 30-40 age group gets more feedback about their performance while 40-50 age group thinks that they do not get enough feedback on their performance as shown in Table 6.

Table6 :Kruskal-Wallis according to age

\begin{tabular}{|l|l|l|l|l|}
\hline Item & Age & Freq. & Mean & Sig. \\
\hline Giving feedback on person performance & $20-30$ & 18 & 2.277 & \multirow{2}{*}{0.11} \\
\cline { 2 - 4 } & $30-40$ & 21 & 1.571 & \\
\cline { 2 - 4 } & $40-50$ & 3 & 3.000 & \\
\cline { 2 - 4 } & Total & 42 & 1.976 & \\
\hline \multirow{2}{*}{$\begin{array}{l}\text { Degree of liking your work. How much it be } \\
\text { must be-30 }\end{array}$} & 20 & 8.222 & \multirow{2}{*}{0.23} \\
\cline { 2 - 4 } & $30-40$ & 20 & 9.200 & \\
\cline { 2 - 4 } & $40-50$ & 3 & 8.000 & \\
\cline { 2 - 4 } & Total & 41 & 8.682 & \\
\hline
\end{tabular}

Kruskalwalis test used to find difference according to duration of service. Two items from performance section are found significantly different with sig. value less than 0.05 as shown in Table 7 . Older workers and new started workers $(<1$ years) stated that they do not use time efficiently. Moreover, older workers do not Keep the institution's policies, strategies and general objectives in front of their own aims while 8-15 years experienced people do that much better than others groups. 
Measuring job satisfaction, performance criteria and job life quality: Bingol City banking case

Table 7:According to duration of service

\begin{tabular}{|l|l|l|l|l|}
\hline Item & Years & Freq. & Mean & Sig. \\
\hline \multirow{4}{*}{ Use time well } & $<1$ & 7 & 2.571 & \multirow{2}{*}{0.025} \\
\cline { 2 - 4 } & $1-3$ & 6 & 1.333 & \\
\cline { 2 - 4 } & $3-8$ & 23 & 1.608 & \\
\cline { 2 - 4 } & $8-15$ & 4 & 1.750 & \\
\cline { 2 - 4 } & $15+$ & 2 & 4.500 & \\
\cline { 2 - 4 } & Total & 42 & 1.881 & \\
\hline Keep the institution's policies. strategies and & $<1$ & 7 & 1.428 & \multirow{2}{*}{0.021} \\
\cline { 2 - 4 } general objectives in front of their own aims & $1-3$ & 6 & 1.500 & \\
\cline { 2 - 4 } & $3-8$ & 23 & 1.739 & \\
\cline { 2 - 4 } & $8-15$ & 4 & 1.000 & \\
\cline { 2 - 4 } & $15+$ & 2 & 4.000 & \\
\cline { 2 - 4 } & Total & 42 & 1.690 & \\
\hline
\end{tabular}

Second survey: Life Quality MeasurementResults

The marital status of the respondents is $52.6 \%$ married and $47.4 \%$ single.The age distribution of the respondents is as follows: $63.2 \%$ between the ages of $21-30,31.6 \%$ between the ages of $31-40$ and $5.3 \%$ over 40 years of age. By looking at the survey results, we can say that the participants are young as found in the first survey. The educational statuses of the participants are 5.3\% high school, $15.8 \%$ associate degree, 52.6\% bachelor degree and $26.3 \%$ bachelor degree. We can say that the level of participants' education is high. $73.7 \%$ of the respondents are officers and the remaining $26.3 \%$ are managers. Work experience of the survey participants is distributed as $42.1 \%$ of them between $1-5$ years, $47.4 \%$ between 6-10 years and $10.5 \%$ between $11-15$ years. This shows that the banks select young and dynamic employees who are able to use today's technology by choosing younger ones in order to be able to serve their customers well. The income distribution of the respondents is as follows: $15.8 \%$ of them have 1301- $2000 \mathrm{TL}(€), 47.4 \%$ of them have between 2001 $3000 \mathrm{TL}(€)$ salary and $36.8 \%$ of them have $3001-4000+\mathrm{TL}(€)$ salary. This is because the majority of the participants are at the beginning of their civil service life, yet they are still in the standards of country income level.

4 point likert-scale(Never-Sometimes-Mostly-Almost always) is used to measure the life quality of workers. $63.2 \%$ of them think that "I think I have problems that others do not have" while just $26.3 \%$ of them selected never option in that question. This shows that workers need psychological support for their working life. 52.6\%, 21.1\% and 5.3\% of workers selected sometime, mostly and almost always "Why do I always react like this" 
question. It is expected that bank staffs are to be calmer against any costumers or management reactions. $5.2 \%$ and $15.8 \%$ of staffs chose mostly and almost always "Now I think I'm insensitive and I do not feel anything." respectively. Sometimes people may think that they do not react according to what they do, but it is quite natural that they think so because they do not reflect the reaction. But people react whatever they are, but they may not reflect it out as a requirement of their business.52.6\% and $21.1 \%$ chose mostly and almost always for "I think if I continue to feel like this I cannot concentrate on anything" question. $21.1 \%$ and $21.1 \%$ of them select mostly and almost always for "I think what I did to deserve it". $26.3 \%$ and $15.8 \%$ of them select mostly and almost always for "I think how passive and demotivated I feel." It is natural for people to get caught up in such feelings when they cannot give themselves up to their jobs. The way to get rid of it is to get the feeling of not thinking these feelings by getting support from the people who are safe like the manager. "I think I do not want to do anything" item is selected by $15.8 \%$ and $21.1 \%$ of them for mostly and almost always options. The long-term intensive tempo of work causes the person to be frustrated and the desire to escape from his work as soon as possible and not to do business. As administrators are careful in this regard and trying to get the highest yield from them by distributing the work force on the staff as much as possible both eliminates these problems and prevents them from running. "I think how sorry I am" is selected by sometimes with 57.95 , mostly with $21.1 \%$ and $18 \%$ with $15.8 \%$ that people cannot easily get rid of the adverse events that they are experiencing, so if they think that the mistake is happening in due to them, but thought make their mind busy, and they may experience difficulties in getting rid of these thoughts. It is beneficial for people to be more careful not to cause such troubles. It is also possible for people to feel sad when they react to the events and to stay for a long time under the influence of the event. About $26.4 \%$ of them have concentration problems almost always that people who have problems in their work are harder to concentrate on works and they cannot get them to the work. This lack of concentration brings failures in business. This must be absolutely eliminated. "I think I'm tired and I'm suffering" item is selected $15.8 \%$ with almost always and $26.3 \%$ mostly and just $26.3 \%$ chose never option. who work hard in intense temp do not feel rested and they feel tired and suffering.

"Work life of me is close to my ideal in most ways" is selected with 3.1 through 1-5 Likert (never agree to completely agree) that they agree with that item. It is very important for people to like their work in terms of business performance. "Working in the bank they do lovingly" means 
getting rid of the unfavorable conditions that may be possible. "My out-ofwork experience is close to the ideal in many ways" is chosen with mean of 3.26 that people have a life outside the work as well as business life. People who are not happy in their work usually try to keep it out of the business life and if they are able to do so, they try to overcome the problems they have in their jobs. The mean for work life satisfaction is 3.15 that they are in neutral section. "Life outside of work is perfect" item mean is 2.73 that normal life is also difficult. "The conditions of my work experience are perfect" item has mean of 2.78 that working conditions like late working hours are not enough for them. About $15.8 \%$ of them think that they are in a kind of depression. $36.8 \%$ of them states that they see themselves happy and $26.3 \%$ of them feel they are very satisfied with the job and $31.6 \%$ of them feel that work day will never finish. "I really enjoy my work" item mean is 3.10 that they are neutral about the work enjoyment. "I can comfortably deal with difficulties because I always trust my talents" has mean of 3 that they are not qualified enough to fight difficulties. "It is not hard for me to realize my designs and reach their goals" and "whatever happens, I usually come from above" items have means of 3.05 and 3 respectively.

\section{Future study of the research}

The study was conducted on the banking sector and it cannot be generalized to other fields and sectors. The geographical status of Bingöl city is different from other cities of Turkey that Bingöl city is economically and culturally is less developed. Hence, this study can be limited just Bingöl city and the same study can be applied other cities of country for comparison purposes.

\section{Conclusion}

According first study, the workers are mainly young and do not have high experience. Their main expectations are high salary and job security. In 2016, country has a coup-try and many people are afraid of losing job due to martial law. Workers are not mainly happy with their work and neutral of job satisfaction. They are not satisfied about their work, but they have to work in high unemployment country conditions. 30-40 age group like their work more than other groups. Older workers and new workersdo not use time efficiently. Moreover, older workers care more own aims while 8-15 years experienced people give more values and priority to banks strategies and aims. Older workers think that they do not get enough feedback about their performance while 30-40 age group workers get more feedbacks. Obeying working hours, good relationships with superiors and 
subordinates and well and clean dressed are the most effective factors found for performance and promotions while personneldevelopment for the progress in the banks and abilities like creativity are not effective factors. Physical conditions and wage are not at satisfactory level and workers support more discussions and being a part of decisions in management of banks.

In the second study, it is seen that the distribution of working time is between 1-5 years mainly composed of young and unmarried employees with high educational level. Sometimes when people are working in a busy work environment, they may experience some difficulties related to themselves. In order to get away from such problems, it is an important necessity to get personal development and psychological support. As the questionnaire suggests, such problems are quite numerous. The long-term intensive tempo work of people causes the person to be frustrated and the desire to escape from his work as soon as possible and not to do business. As administrators are careful in this regard and trying to get the highest yield from them by distributing the work force fairly on the staff as much as possible both eliminates these problems and prevents them from running smoothly. The same is true of the participation Bank in Bingöl. In case of intensive work tempos, staffs worry about job loss and future worries in case of being below the expected target and below expectations. At the same time, the inadequacy of the wages paid despite the overworked workloads in the lower units reduces the motivation. Having a certain age and being in a certain position in the society such as in the managerial position makes themunhappy and worried about not being able to find jobs in the same positions in case of losing their job after a certain age which leads to lack of motivation, causing a negative effect on the employee. Lack of motivation also prevents the employees from synchronizing with their teammates and customers. This has resulted in reducing their wealth and quality of life as other bank unit employees.

\section{Acknowledgement}

I want to give my special thanks to my undergraduate student Azad Adiyaman for carrying out first survey and my master student Ebru Ataoğlu for carrying out second survey diligently.

Without their contributions, I will not be able to prepare this study. 


\section{Measuring job satisfaction, performance criteria and job life quality: Bingol City banking case}

\section{References}

Azash S, Safari R, Thirupalu N, Subhan B (2012). "Job characteristics as predictors of work motivation and job satisfaction of bank employees", International Journal of Business and Management Tomorrow, 2(1): 1-7.

Abiyev R.H., Saner T., Eyupoglu S., Sadikoglu G. (2016) "Measurement of job satisfaction using fuzzy sets", Procedia Computer Science, 102 , 294 -301.

Ahmed S., NokirUddinMD. (2012) "Job Satisfaction of Bankers and its Impact in Banking: A Case Study of Janata Bank”, ASA University Review, Vol. 6 No. 2.

Agbozo G.K., Owusu I.S, Hoedoafia M.A \&AtakorahY.B. (2017) "The Effect of Work Environment on Job Satisfaction: Evidence from the Banking Sector in Ghana", Journal of Human Resource Management. Vol. 5, No. 1, 2017, pp. 12-18.doi: 10.11648/j.jhrm.20170501.12

Aslan I. \&Hakiye Aslan H. (2016) "Halal Foods Awarness and Future Challenges", British Journal of Economics, Management \& Trade, 12(3): 1-20, 2016, Article no.BJEMT.23861, ISSN: 2278-098X.

Aslan I. \&BektaşÇ.(2016) “Analyzing Burnout Syndrome at Bingol University”, BE-ci 2016 : 3rd International Conference on Business and Economics, 21 -23 September, Kuala Lumpur, Malaysia, pp:43-63, http://dx.doi.org/10.15405/epsbs.2016.11.02.6

Aslan, I.(2017). "Interest free banking: reasons for choosing Islamic banking in Bingöl city”, PressAcademia Procedia (PAP), V.3, p.257-268.

BayirF. ZZelhaAltinkaya, Mammadova A.(2017) "Modern PerformansDeğerlemeYöntemleriveAzerbaycan' dakiİşletmelerdeUygulanması” http://abmyod.aydin.edu.tr/makaleler/sayi_43/modern-performans-degerleme-yontemlerive-azerbaycan\%E2\%80\%99daki-isletmelerde-uygulanmasi.pdf (Access Date:17.12.2017)

Bakan, İ., \&Kelleroğlu, Ö. G. H. (2003). "PerformansDeğerlendirme: ÇalışanlarınPerformansDeğerlendirmeUygulamalarındanBeklentileriKonusundaBir Alan Çalışması.”SüleymanDemirelÜniversitesiİktisadiveİdariBilimlerFakültesiDergisi, 8(1).

Chaha A., Chahal S., Chowdhary B., Chahal J.(2013) "Job Satisfaction Among Bank Employees: An Analysis Of The Contributing Variables Towards Job Satisfaction", International journal of scientific \& Technology research, Volume 2, Issue 8, ISSN 2277 8616.

Cetin M., KarabayM.E ,Efe M.N.(2012) "The Effects of Leadership Styles and the Communication Competency of Bank Managers on Employees' Satisfaction: The Case of Turkish Banks”, Procedia - Social and Behavioral Sciences, 58 , pp:227 - 235.

Çınar O., Bektaş Ç., \& Aslan I. (2011). A motivation study on the effectiveness of intrinsic and extrinsic factors. Economics \& Management, 16, 690-695.

Deci, E. L., \& Ryan, R. M. (2000). The "what" and "why" of goal pursuits: Human needs and the self-determination of behavior. Psychological Inquiry, 11, 227-268.

Belias D., KousteliosA.( 2014) “ Transformational Leadership and Job Satisfaction in the Banking Sector: A Review", International Review of Management and Marketing, Vol. 4, No. 3, 2014, pp.187-200, ISSN: 2146-4405. 
Belias D., Koustelios A., Sdrolias L., Aspridis G.(2015)“Job Satisfaction, Role Conflict and Autonomy of employees in the Greek Banking Organization", Procedia - Social and Behavioral Sciences , 75, $324-333$

Daft, Richard L. and Marcic, Dorothy. 2013.”Understanding Management”. 8th Edition. South-Western Cengage Learning.

Eren S.S., Ayas N., HaciogluG.(2013) "The effect of service orientation on financial performance: The mediating role of job satisfaction and customer satisfaction", Procedia Social and Behavioral Sciences, 99, PP.665 -672.

Gautam, P. K. (2016). Determinants of Job Satisfaction and their Effect on Organizational Performance : An Evidence from Nepalese Banking Sector. THE BATUK: Journal of Interdisciplinary Studies, 2(2), 43-54.

Hayati K. \&Caniago I. (2012) "Islamic Work Ethic: The Role of Intrinsic Motivation, Job Satisfaction, Organizational Commitment and Job Performance" , Procedia - Social and Behavioral Sciences, 65, pp.102 - 106.

Heskett, J.L., Sasser, W.E., Schlesinger, L.A. (1997).The service profit chain. New York: Free Press. In: Emery, C.R. \& Barker, K. (2007). The effect of transactional and transformational leadership styles on the organizational commitment and job satisfaction of customer contact personnel. Journal of Organizational Culture, Communications and Conflict, 11, 1, pp.77-90.

Leontaridi, R. \& Sloane, P., Measuring the Quality of Jobs: Promotion Prospects, Low Pay and Job Satisfaction, Lower Working Paper n.7, University of Amsterdam, 2001.

Islam S. \&Mainul Islam M. "A Comparative Study of Job Satisfaction in Banking (A Case Study of Public and Private Bank Sectors)", European Journal of Business and Management, ISSN 2222-1905 (Paper) ISSN 2222-2839 (Online), Vol.6, No.21.

Nabi NM, FoysolKM and Adnan SM (2017) "The Role and Impact of Business Communication on Employee Performances and Job Satisfactions: A Case Study on Karmasangsthan Bank Limited, Bangladesh", Arabian J Bus Manag Review 2017, 7:3, DOI: $10.4172 / 2223-5833.1000301$

Mishra U.S. , Patnaik S. , Mishra B.B. (2016) "Role of Optimism on Employee Performance and Job Satisfaction”, June 2016, DOI: 10.17010/pijom/2016/v9i6/94960.

Raziq A., MaulabakhshR.(2015) "Impact of Working Environment on Job Satisfaction”, Procedia Economics and Finance 23, pp.717 -725.

Saner T.\&Eyupoglu S.Z. (2015)" The Job Satisfaction of Bank Employees in North Cyprus", 2nd Global Conference on Business, Economics, Management and Tourism, 3031 October 2014, Prague, Czech Republic, , Procedia Economics and Finance 23 ( 2015 ) $1457-1460$

Sattar T. , Ahmad K. and Hassan S.M.(2015) "Role of human resource practices in employee performance and job satisfaction with mediating effect of employee engagement", , Pakistan Economic and Social Review, Volume 53, No. 1, pp. 81-96

Schermerhorn, J.R. \& Osborn, R.N. \&Uhl-Bien, M. \& Hunt, J.G. (2012). “Organizational Behaviour; experience, Grow, Contribute.”, 12th Edition. John Wiley and Sons, Inc.

Singh, A. P. and Singh, S. (2009): Effects of Stress and Work Culture on Job Satisfaction, The Icfai University Journal of Organizational Behavior, Vol. 8, No. 2: 154-164. 


\section{Measuring job satisfaction, performance criteria and job life quality: Bingol City}

banking case

UkilM.I. , Muhammad ShariatUllah M.S. (2016) "Effect of occupational stress on personal and professional life of bank employees in Bangladesh: do coping strategies matter", Journal of Psychological and Educational Research, 24(2):75-100

Yaşlığlı M., Karagülle A.Ö, Baran M.(2013) “An Empirical Research on the Relationship between Job Insecurity,Job Related Stress and Job Satisfaction in Logistics Industry", Procedia - Social and Behavioral Sciences, 99 , pp.332 -338

Wilkinson, A.D., \& Wagner, R.M. (1993). Supervisory leadership styles and state vocational rehabilitation counselor job satisfaction and productivity. Rehabilitation Counseling Bulletin, 37(1), 15 -24.

Zheng, C. and D. Lamond (2010), Organizational determinants of employee turnover for multinational companies in Asia. Asia Pacific Journal of Management, Volume 27(3), pp. 423-443. http://dx.doi.org/10.1007/s10490-009-9159-y 